\title{
Field of Dreams: Imagining Development and Un- Development at a Gas Field in Sylhet
}

Katy Gardner, Zahir Ahmed, Mohammad Masud Rana and Fatema Bashar

\section{OpenEdition}

1 Journals

Electronic version

URL: http://journals.openedition.org/samaj/3741

DOI: 10.4000/samaj.3741

ISSN: 1960-6060

Publisher

Association pour la recherche sur l'Asie du Sud (ARAS)

Electronic reference

Katy Gardner, Zahir Ahmed, Mohammad Masud Rana and Fatema Bashar, « Field of Dreams: Imagining Development and Un-Development at a Gas Field in Sylhet », South Asia Multidisciplinary Academic Journal [Online], 9 | 2014, Online since 23 July 2014, connection on 05 May 2019. URL: http://journals.openedition.org/samaj/3741 ; DOI : 10.4000/samaj.3741

This text was automatically generated on 5 May 2019.

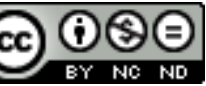

This work is licensed under a Creative Commons Attribution-NonCommercial-NoDerivatives 4.0 International License. 


\section{Field of Dreams: Imagining Development and Un-Development at a Gas Field in Sylhet}

Katy Gardner, Zahir Ahmed, Mohammad Masud Rana and Fatema Bashar

\section{Introduction}

1 Whether viewed as a 'basket case' for aid in the 1970s or, more recently, as the home of Nobel Prize winner Mohammed Yunus's pioneering projects of micro-credit and ongoing success in improving key indicators of living standards, ${ }^{1}$ it's hard not to imagine Bangladesh in terms of development. Just as the country tends to be represented internationally in these terms, the discourse of development is also used by Bangladeshis to frame their hopes for a better life (Guhathakurta \& van Schendel 2013: 411-469, Lewis 2011, White 1994). Within Bangladesh unnoyon (development) is a catch all for notions of progress, economic growth and modernisation which is neither homogenous nor fixed but which everyone aspires to. As has been noted in other contexts, such 'development talk' can be a way of dreaming of new and better futures (Cross 2014, Abram \& Weszkalnys 2013). It can also be used to critique the existing state of affairs; if development is the dream, it is shadowed by its nightmarish antonym or lack: undevelopment, 'backwardness', poverty and corruption (see Howard Smith 2008, Jordan Smith 2007). And whilst development might be a state that is aspired to, its aetiology is not assured (Hussain 2013).

2 As this implies, development (unnoyon) is a powerful rhetorical device in Bangladesh. As an aspiration and a dream, it can be called upon and utilised in making as well as denying claims, a discursive site which is often underlain by bitter struggles over material resources. In order to illustrate this, in what follows we analyse the discourses and narratives which surrounded a Chevron operated gas field in Sylhet during its first years of operation, from 2008-2011. We draw upon ideas of development, or its absence, and reference dreams and nightmares of the future. Our observations are based on two very 
different and seemingly incommensurable sources. On the one hand are narratives arising from Chevron's Community Engagement Programme, which conjure up an appealing picture of community development, entrepreneurship and 'empowerment', relying upon idioms of sustainability and 'helping people to help themselves'. These represent Bangladesh as essentially 'in need of change', drawing upon globally appealing notions of gratefully empowered peasants ${ }^{2}$ which assist the corporation in marketing itself as an ethical business that extends the hand of partnership to all those lucky enough to live on or near land where resources are to be extracted. After all, Chevron's community liaison officer told us that before they arrived in the area with their programmes 'there was nothing here'. On the other hand are the narratives of people living in the villages surrounding the installation. Whilst for them, dreams of unnoyon involve the provision of local services, access to gas and the creation of jobs, their accounts from our research of what the gas field actually led to revolve around tropes of environmental destruction and disastrous rupture: a dystopian anti-development.

Our material is drawn from a research project funded by the ESRC-DFID which took place from 2008-2011. Whilst the project's main objective was to understand the impact of the new gas field on social networks and transnational relationships in the surrounding villages, much of our work focussed upon the corporate social responsibilities programmes which Chevron was funding. The research involved fieldwork in two villages which focussed on household livelihoods and coping mechanisms and was carried out by Fatema Bashir and Masud Rana; unless otherwise specified, the interviews referred to in this paper were carried out in Bibiyana by the research team in 2008-09. Interviews with leaders in Britain and Bangladesh and with transnational communities in the U.K. were carried out by Zahir Ahmed and Katy Gardner; and interviews with Chevron officials carried out by Katy Gardner. Longitudinal perspectives were drawn from Gardner's longterm research in one of the villages adjacent to the gas field (Gardner 1995, 2012). As we were to discover, representations of the gas field and the presence of Chevron in the area were sharply polarised between those who argued that the corporation were a benign presence who would bring a particular kind of development to the villages, and those who contested their presence.

\section{The gas field}

4 As Gardner has documented in her research on transnational migration in the area, the villages surrounding the gas field have always been connected to the global economy, first via the migration of ship workers to the docks of Calcutta in the early $20^{\text {th }}$ century, and over the last two generations, by long term migration and settlement to the U.K. (Gardner 1995, 2008, 2012). The discovery of natural gas connects the area in a different way by placing it on the periphery of an industrial zone, the location of the biggest gas field in the country, which the country depends upon for its ongoing output. Indeed, when the installation temporarily shut down due to technical problems in June 2013, households in Dhaka as well as power plants and factories across the country were cut off, leading to a short lived national crisis. ${ }^{3}$

5 Natural gas was discovered in the area as long ago as 1990. In 2000 Unocal developed a small installation a few kilometres south of the current location of the main 'pad'. By 2004-2005 a much larger development was being planned using around sixty acres of prime agricultural land. The land was forcibly acquired by the Bangladeshi government 
and rented to Unocal, who were contracted to develop the site. In 2005 Unocal merged with Chevron and in 2007 the gas field went into production, joining other gas fields operated by Chevron in Moulvi Bazaar and Jalalbaad. Today, Chevron produces nearly $50 \%$ of Bangladesh's gas.

Given the forcible loss of land, it is hardly surprising that the gas field initially met with substantial local resistance. As soon as people heard of the plans 'Demand Resistance Committees' were set up and a series of demands put to Unocal: the rate of land compensation was high on the list, as was connection to the gas supply, which even in 2014 has still not been provided. A school, a hospital, a fertiliser factory and improved roads were also demanded. Today, people say that Unocal agreed to these stipulations. If this was the case they were making promises they could never keep: rates of compensation, the piping of gas to the communities and the development of power plants and factories were not in their power to give; these are all determined by the government. The negotiations took place in a context of passionate agitation: from the perspectives of the landowners, they were about to lose an irreplaceable resource which sustained not only their own households but also those of many people around them; for some it seemed almost like a loss of self. As one of the local men who lost the most land told us: 'The day they grabbed my land, I lost my words. If I remember that day I have to stop myself from going mad.'

7 In 2005 the road was blocked by protestors in an attempt to stop construction. The police were called, threats made by the District Commissioner, arrests made and writs issued. Whilst some local leaders tried to hold out against the inevitable, others started to negotiate. By this time Chevron had taken over Unocal and the compensation process was underway: this was for land and property taken in the building of the plant and the roads that surrounded it. Today Chevron say that $95 \%$ of land-owners were properly compensated at the highest rate they could negotiate with the government. Local grievances dovetailed the national resistance campaign against the extraction of Bangladesh's natural resources by foreign companies. In 2006 protests against a proposed open cast mine in Phulbari, in north east Bangladesh, to be operated by Asia Energy, led to three people being killed and around a hundred injured (Nuremowla 2011, Faruque 2012, Gain 2006). Meanwhile, national agitation centred around the content of Production Share Contracts with foreign companies, with activists arguing that these grossly exploit the country's natural resources, leading to large profits for the multinationals, generous backhanders for corrupt government officials and nothing for Bangladesh. In 2009, for example, a rally called to protest against the leasing of rights to extract off-shore gas resources to multinationals led to police violence and the thirty people being injured. Rumours, counter rumours, civil unrest, accusations and arrests are common in a fragile democracy marked by high levels of government corruption, secret deals and little accountability (Alam \& Al Faruque 2009).

\section{Dreaming of development: local hopes of connection to the gas field}

8 It is important not to consider protest against the loss of land to the gas field or the presence of Unocal / Chevron, as synonymous with protest against development per se. The inhabitants of the villages surrounding the gas field were keen to be connected to the gas supply, to the jobs that they hoped Chevron would supply, and more generally to the 
modernity and industrialisation that the gas field represented. As Jamie Cross argues with reference to the development of Special Economic Zones in India, large scale infrastructure is 'built upon an economy of anticipation [...] (for) contemporary capitalism is built upon dreams as well as nightmares (Cross 2014: 6-7, see also Abram \& Weszkalnys 2013). The accounts of local and transnational villagers from the early days of the gas field are filled with hope for the future, although tinged with apprehension. Many people were conflicted: angry at the loss of land and with a strong sense that the gas was a local resource which should benefit locals and not foreign multinationals, yet hopeful that the plant would bring substantial economic development.

These views were shared amongst transnational villagers. As our interviews in the U.K. revealed, alongside nostalgic images of the 'shonar desh' (golden land, evoking images of ripe paddy fields) is another equally desirable landscape of 'development': reliable infrastructure, brick houses, a dependable power supply, and industrialisation. One man, for example, said that he had no problem with industrialisation per se, but if this was to take place, he should profit from it, not a foreign multinational. A local councillor in the north of Britain emphasised that in his view, the gas plant made a 'great visual impact' on the area and its construction had led to better transport links. He was proud to see development taking place in his homeland; he went on to say that he hated returning home and being reminded that in Bangladesh things were not 'up to scratch'. Similar attitudes are shared in the villages surrounding the gas field. 'Of course it's good if the area becomes industrialised', the matriarch of a middle income family replied, in response to our questions; 'then there'll be development and the lot of the poor will improve'.

10 It was partly due to these hopes that the protestors started to negotiate with Chevron in 2005. As one of the leaders recounted: 'They promised that gas would be provided to the houses, young men would get jobs, electricity would be available: no more darkness.' Crucially, according to the Baseline Survey produced by consultants for Unocal, one of the main demands that were made in a focus group discussion in 2004 was that the gas field should employ local people (Centre for Women and Child Studies 2006). The early days of constructing the gas field bore out these hopes. Many hundreds were employed as labourers, helping to build the plant and surrounding infrastructure. The wages were good, but the work was much less secure than people realised. In contrast to skilled labourers who are recruited directly by Chevron at national and international levels, local labour was employed via contractors, who tendered for the work on the plant's behalf. Once given the contracts, Chevron enlisted them as private 'companies'. Whilst some local leaders were given contracts to supply labour to the gas field, our research showed that of fifteen enterprises contracting labour in 2009, only half were from the immediate vicinity, whilst the rest came from outside the area, some bringing in labourers from hundreds of miles away. The advantages to Chevron are easy to understand. Since the contractors recruit and pay the workers, the company does not need to have any direct dealings with them. They are therefore a reserve army par excellence, un-unionised and with no form of redress from the company; their contract offers none of the ethically irreproachable standards of employment that Chevron reserves for its own staff who, during the time of our research, came from outside the area or were foreign. As the then community liaison officer told us, these employment policies provided 'an easy flow of labour'. After all, contractors explained, bringing labourers from far away meant they were less likely to cause trouble. ${ }^{4}$ 
11 Whilst in 2005-2007 there were around 500 construction jobs, once the installation was complete the labourers were laid off. For now there was to be no connection to the gas supply or secondary industrial development. Instead, once the process of land compensation was completed-and many of the landowners who received compensation lived in the U.K.- local people found themselves living next door to a gas field surrounded by high fences which had little to with them. It is true that there was a programme of 'community engagement' but this was largely run by NGOs and Village Development Organisations which were made up by members of the local elite. As we describe elsewhere (Gardner et al. 2012), Chevron was pursuing 'partnership' and at the same time following the corporate ethics of detachment (Cross 2011).

Meanwhile, the local eco system was significantly altered. The high banked roads that linked the 'pads' over the fields blocked the flow of water across agricultural land during the wet season, leading to the water-logging of some plots and aridity of others. Farmers noticed increased amounts of sand in the soil and complained bitterly about the culverts that Chevron had built: they were too small and had quickly been blocked with fena (waterweeds), making the passage of water impossible. The roads were also too high for the movement of cattle across fields. Other people, mostly from the landless households in the poorer villages, bemoaned the shrinking of their livelihoods. The gas field had offered work for a short amount of time, but now they were unemployed (bekar).

In railing against Chevron, which was accused of 'looting our gas whilst giving nothing back to us', ${ }^{5}$ local narratives of dispossession and impoverishment focussed on the gas field in describing wider processes of monetization and the shrinking of agricultural livelihoods in the area. Farming was 'too expensive'; the costs of inputs and labourpartly inflated by the gas field but also moving apace with inflation across Bangladeshmade it unprofitable. Sharecropping arrangements had also changed, putting the onus on the sharecropper to buy seeds, fertiliser and the means of irrigation. Rather than relying on agriculture, most households in our study villages were following a strategy of mixed livelihoods, including driving rickshaws or vans, day labouring, small business ventures and for the women, domestic labour. Chakri (regular salaried employment in the formal sector) was profoundly desired, but during our research we found that it was only available from the gas field for a small minority who had managed to gain access to employment via local labour contractors. In sum, the transformations in agrarian livelihoods which have been reported over much of South Asia, involving a shift from fields to factories for some, and uncertain, precarious futures for the majority, was rapidly taking place (see Corbridge \& Shah 2013, Ito 2002, Le Mons Walker 2008, AkramLodhi 2009, Feldman \& Geisler 2012, Adnan 2013, Guhathakurta 2013).

From this brief background, let us turn to Chevron's programme of 'community engagement' and its imaginary of Bangladeshi development. Carefully crafted via newsletters, power point presentations and reports, the programmes and the PR campaigns which narrated them drew from both national aspirations and imaginings of development success as well as from global imaginings of Bangladesh as a place in need of improvement. It was aimed not at local people, but at the urban middle class of Bangladesh, Chevron staff and a global audience of consumers. As the company's CEO of Bangladeshi operations explained, the primary objective of community engagement programmes was the management of reputation. ${ }^{6}$ 


\section{'What we're doing is empowering people':? imagining development, Chevron style}

15 As anthropologists have noted, a major objective of the Corporate Social Responsibility (CSR) Programmes of mining companies is to gain a 'moral license to operate' which masks the often violent histories of land appropriation involved (Welker 2009, Zalik 2004, see also Rajak 2011). The aim of many programmes is to create a local population of selfreliant entrepreneurs, ideological work that lies at the heart of the neoliberal project (Ong 2006). At the Batu Hijau mine in Indonesia, for example, potentially oppositional farmers are encouraged to adopt neo-liberal subjectivities via 'participatory' agricultural training, even though most reject the opportunity to be 'empowered', instead demanding compensation (Welker 2012). Shell has pursued similar tactics in Buenos Aires, using gendered techniques to 'refacialise' the company via pictorial representations of brown skinned, smiling women, and offering partnerships to the local population, suggesting that together they will overcome the adverse environmental problems which they face (Shever 2010). Meanwhile Rogers has described how in the Perm area of Russia, oil companies utilise images of depth and connectivity in their CSR campaign, eliding the material qualities of oil and infrastructure with local features which they are investing in (the depth of oil and the depth of local culture, and the connections of infra structure with social networks for example) in order to naturalise their presence and stifle criticism (Rogers 2012).

We suggest that Chevron's promotional literature and programmes of corporate social responsibility attempted a similar manœuvre, discursively placing the corporation at the heart of what matters in Bangladesh: not cultural depth as in the Perm region, but unnoyon: development. Created for a national and global audience rather than being aimed at the poorest sections of the local population who hoped for something different, community engagement projects in the villages surrounding the gas field attempted to fuse Chevron's brand with that of Bangladeshi development success, as embodied in the first instance by internationally renowned NGOs and in the second by nationalist eulogies of fortitude, hard work and progress. By producing 'communities' with which to 'partner', and an array of globally fashionable techniques such as Participatory Rural Appraisal, micro-credit and training, poverty was imagined as a technical problem that could be 'solved' via remedies such as credit or training, rather than a political problem caused by global and local relationships. 'Helping people to help themselves' was the line taken, whilst the jobs, services and inclusion that people wanted did not figure. Just as Rogers notes, with reference to oil company imaginings of regional cultural development in Russia, these discursive tropes were not consciously wielded corporate strategies (Rogers 2012: 291). Instead, they arose from the widely circulating discourses of Bangladeshi development and nationalism: fertile grounds within which to build new images of Chevron as a friendly and ethically irreproachable corporation.

In planning their projects at the newly inaugurated gas field, Chevron's first step was to hire development consultants to 'map' the area (Chevron 2008: 11). Later came the participatory rural appraisal exercises in which problems were diagnosed and the field of action delineated (Li 2007: 246). The knowledge gained from these exercises was written up in more reports, and the 'problems' (the loss of livelihoods to the gas field / poverty) transformed into 'project goals' (Chevron Annual Report 2006-2007). Like all development 
projects, the solutions offered by the reports were technical in nature; as the anthropology of development has taught us, schemes of improvement are powerful conceptual and practical devices for rendering political problems technical (see Ferguson 1990). As a result of these 'scoping exercises', project objectives began to materialise, all of which found the solutions in strengthening community and individual capacity via training and marketing support. Village Development Organisations (VDOs) were set up which would involve committees of 'local leaders' who, alongside NGO field officers, would choose beneficiaries for the credit and training. Whilst being offered supplementary training in accounting and book keeping, the VDOs were modelled on a notion of 'natural communities', in which leaders speak for, and know, 'the people' and in which the role of development is to strengthen and modernise these structures, provide training and improve access. The nature of relationships within communities, in which the elite (i.e. 'the local leaders') essentially dominate and exploit the labour of the poor, was conveniently ignored (see also Pattenden 2010).

Meanwhile slab latrines were distributed to households without hygienic sanitation and tin roofs and concrete pillars were supplied to low income housing, all sporting the Chevron logo. The company could not provide piped gas, but it distributed smoke free chulas (stoves). Two medical clinics were built, run by an NGO, and partly funded by the donations of Londonis. These provided diagnostic services but not medicine, with a further programme of outreach health workers, and an ambulance which could take patients to the nearest hospital in Sylhet, though at a cost. Whilst not actually building a school, Chevron provided support for four high schools in the area via the funding of teachers and teaching materials, the distribution of school uniforms and providing several hundred scholarships for pupils each year. The clinics and scholarships were part of Chevron's objective of creating 'sustainable' development and community 'partnership' which in turn allowed them to make claims about their moral right to extract gas in the area (see Zilak 2004).

The ideal of 'sustainable development' seems morally unquestionable. Who, after all, wants to create dependency? As the CEO of Chevron Bangladesh told Gardner, the locals of Bibiyana 'are a proud people' who eschew hand-outs and want to be helped to help themselves: 'You know [...] give a man a fishing rod'. ${ }^{8}$ It is this ethos which underlay the Alternative Livelihoods Programme (ALP); indeed, the programme offices were decorated with a banner proclaiming the aim of 'helping people to help themselves'. One of the main activities of the ALP were loans and savings programmes, made available to small scale entrepreneurs who use the credit to fund a variety of livelihood activities such as goat rearing, broiler farms, and fisheries. VDO members were trained in accountancy so that they would eventually function without support. There was also an adult literacy programme and a sewing programme for local women, in which training was given on sewing machines and a market supplied for the pieces of embroidery that the women produced. The Director of External Affairs at Chevron Bangladesh told Gardner that the goal of these programmes was 'empowerment' (see Batliwala 2007). In the following, taken from the company's annual report on Bibiyana, a satisfied recipient of training and credit gives testimony to how the ALP has turned his life around:

I just feel exhilarated when I go to my vegetable farm. I have learned how to plant and grow vegetables and I have made sure that there will be no insect or pest attacks on my vegetables as I have learned to apply appropriate insecticide at the appropriate time. The villagers who also received training along with me are also successfully applying the scientific method of farming and getting good results [...] 
All my efforts are being directed to the one and only goal, which is farming [...]. By

fulfilling this dream I will drive away poverty from my family. ${ }^{9}$

In this context it is useful to recall David Mosse's insights (2005) on development work as primarily concerned with the performance of success. These involve particular rituals and celebrations, such as 'handing over ceremonies', VIP visits, project literature and brochures, for as Mosse (2005: 168) puts it: 'success is not guaranteed, but produced through processes requiring constant joint work'. Centrally, development reports can be analysed as a particular genre of stories, with common narrative arcs, plot twists and denouements (Cornwall \& Eade 2010, Eyben 2005, Rottenburg 2009). Such representations can also be seen as a form of claim-making in which Chevron are staking out their moral right to operate as well as a world-view in which the market and extractive industries are celebrated for the ability to spread sustainable development, a power of good for the rural poor who require training and access to the goods of neo-liberal capitalism in order to be 'empowered'. In the same report, written in English and distributed at the company's Dhaka office, the largesse of Chevron is celebrated in the following:

Buffie Wilson, wife of Chevron Bangladesh President Steve Wilson recently made a visit to the village of Karimpur [...]. Her visit heralded a brand new beginning for the families of Champa Begum and Jotsna Dev. Both women lost their homes during the devastating flood of 2007 and in standing by the community, Chevron gave them the chance to restart their lives afresh by rebuilding their homesteads. Their homes were officially presented to the proud new owners in a simple, heart warming ceremony and Ms Wilson was accorded a rousing reception. Champa Begum and Jotsna Dev finally found a reason to smile after last year's floods wreaked havoc, chaos and devastation in their lives. ${ }^{10}$

21 A final example shows how even land acquisition, the subject of so much ill feeling and agitation in the area, can be turned into a story of success, in which those who lost land celebrate their contribution to national interests and improvement:

About fifty acres of land were acquired for the development of the [...] Gas Field. of which about eight acres [...] used to belong to my family [...]. Even though our land was acquired in the national interest, I personally think that each of us has been immensely benefitted. The standard of living in our area has risen and the value of land has gone up. People of the area are also held in high esteem because of the project [...]. ${ }^{11}$

\section{The national spirit: development writ large}

Whilst narratives of local projects conjured up images of small scale grass roots development involving self-sufficient peasants empowered by their training in scientific methods, access to credit and strengthened community structures, Chevron's public relations team accessed a different imagining of Bangladeshi development in other contexts. Whilst in the first instance the audience for the tales of development was predominantly global (accessed through annual CSR reports available on the internet), and included shareholders as well as international employees of Chevron, in the second the desired audience was predominantly national. Messages of Chevron's solidarity with Bangladesh in its development effort, which aimed to resonate with nationalist sentiment, attempted to counter the fierce critiques of those protesting against the company's presence in the country. ${ }^{12}$ These messages were materialised in the form of corporate gifts offered to visitors to the company's Dhaka headquarters. 


\section{of tea we read: 'Tea, from the garden of Chevron's neighbourhood.' On the back, we're} told:

Lackatoorah Tea Estate of National Tea co. Ltd., one of the oldest tea gardens in Sylhet, has been growing quality tea for the people both home and abroad for the past 125 years. Chevron, one of the world's leading resources and project development companies, has been contributing significantly to the development of Bangladesh's energy sector.

Here, the colonial history of the tea sector and its obvious parallel with the presence of Chevron and other foreign companies is concealed under an image of economic productivity and contribution to national development. Similar nationalist sentiments are carried on the company calendar. Again, it is Chevron's partnership with Bangladesh the nation, rather than with 'the community' that takes centre stage. Each month of the calendar is illustrated by a beautifully shot photograph of people carrying the Bangladesh flag, with a poetic quotation underneath. For example, July reads: 'You reside eternally in the spirit, / O my homeland; for you / We are adorned with new energy'. On the cover of the calendar, we read:

Human energy, leading Bangladesh with energy and spirit

[...] In Bangladesh, where the people are known for their resilience, Chevron seeks to identify the spirit that guides them and their actions. Bangladesh's national spirit is best exemplified by its people's desire to build a better tomorrow, to strive forward by attaining economic growth and to go beyond the odds with the overriding power of aspiration and hard work. All Bangladeshis play a role in this progressive thrust towards the future by bravely facing myriad adversities and by actively contributing to the realisation of collective goals.

Reducing these imaginings to neo-liberal governance or, in more crude terms, a way of 'buying off' local resistance to the gas plant, misses the more nuanced and complex ways in which business advantage, neo-liberal moralities and PR tactics are interwoven with a range of ideological stances, dreams and aspirations. When asked what motivated him, for example, a high level executive in Chevron Bangladesh told Gardner that in 'work' it was the wish to promote the 'reputation' of the company, whereas at a personal level, he, like so many of his compatriots, wished to harness the might of Chevron to 'do good' for the national betterment of Bangladesh, an aspiration that via the calendar and other corporate gifts, the company sought to evoke. As noted earlier, such gifts are aimed at the urban and professional Bangladeshis who visit the Dhaka offices and bear such gifts away, not the global audience accessed via the world wide web, for whom the idea of 'partnership' with 'empowered' Third World villagers is so seductive.

What did local people think of all this? During our fieldwork we encountered a variety of views, largely depending on whether or not our informants had connections with Chevron as contractors or employees. The majority did not hold a radically different version of the role of Chevron in national and local development, and indeed what global capitalism might mean. Indeed, during our research Chevron's tales of development success were strongly contested by many of our informants. Many told us that the company 'gave nothing', despite the projects they were sponsoring. The small scale, community driven development of the ALP and other interventions was not part of their dream of unnoyon, far less was being 'helped to help themselves'.

South Asia Multidisciplinary Academic Journal, 9 | 2014 


\section{Nightmares of rupture: un- development / disconnection at the gas field}

27 To summarise: whilst Chevron narrated Bangladeshi development in terms of the liberating power of the market, small scale entrepreneurship and a national spirit of resilience to which they wish to be aligned, people living in the gas field's borderlands desired a less photogenic form of development: connection to global capitalism via employment by Chevron. What many faced in 2008-2011, however, was an ongoing process of disconnection or un-development. The gas field had also brought the threat of a 'blow-out', or explosion, in which the physical connection to the gas supply is violently severed and the villages that surround the plant are ripped apart by fire and destruction: industrialisation's darkest side (see also Fortun 2009). During our research, stories and imaginings of such blow-outs were shown to be an important aspect of how people think and talk about the gas field. One woman, for example, told how her cousin had died from worry about a blow-out. This fear of an industrial accident was vividly materialised in 2008 when a standard technical procedure in which excess gas is burnt off in a controlled flare, led to widespread panic. This was described to us by almost everyone in the area as an example of the dangers of the gas field, a terrifying night when they awoke to find the sky 'filled with fire' and ran in terror from their homes. Chevron executives had warned 'local leaders,' who they had imagined would pass the message on to 'their people', but this did not happen, for whilst the 'leaders' told their close families, they were not connected to the poor in the ways that the community relations staff had imagined. The incident, and the fear it invoked, reflects the history of Bangladesh's relationship to multinationals in the gas sector. The government is still seeking compensation for a blowout at Magurchhara in 1997. In 2005 a series of accidents also occurred at the Tengratila gas field, operated by the Canadian company Niko in Sunamganj, Sylhet. In the second blow-out within six months flames leapt up to a height of 150 feet after a loud explosion. As these incidents show, people have a well founded fear of an industrial accident.

We suggest that within local narratives blow-outs can also be read as accounts of violent disconnection and rupture, whether from the transformative energy of the gas with its contradictory possibilities of enrichment and destruction, from the land on which livelihoods depend, or the richly woven web of social connections so vital for everyday survival. Indeed, stories of industrial disaster reveal the profound risks that engagement with neo-liberal capitalism has involved. Within this analysis, a blow-out is merely the most dramatic materialisation of the uncertain world in which people struggle for survival. The accounts that follow are thus narratives borne from terror, ways of making sense of the chaos, panic and speechlessness caused by Chevron's unexpected flare: ${ }^{13}$

Because of the gas field we live under the threat of fire. Like an earthquake, everything moves and there's a roaring sound. When the fire goes up we have to go to a safe place; we fear that the fire will engulf us. The flame is so bright that it illuminates everything even though it's night. If you dropped a piece of sewing on the ground you could find it. We run around madly. Last year Harun's wife was so scared that she fled the house, leaving her children behind. People leave their valuables. Everyone is scared for their life! Whenever Chevron ups the fire our relatives call us to see if we've survived and they live 15 miles away! Some villagers fled by rickshaw. ${ }^{14}$ 
A similar reading can be made of local accounts of environmental change. As with the flaring, these narratives were based upon empirical observation: there were observable changes to the environment. In the first account the trope of 'before' and 'after' is used to organise the speaker's observations of environmental changes which, in his analysis, affect his ability to survive. The analysis is pointedly political: things were promised but not provided. The account ends with a dramatic pronouncement on the risks the speaker faces, where farming can no longer sustain him:

Otherwise we will die. Because of the gas field us farmers are badly affected. Before the gas field the yields were very good. Now we have to deal with scarcity of water; without water the yields are poor [...] it's hard to graze cattle or goats because there's less grazing land. It's difficult to bring cattle from one side of the road to the other because they're so high. Before the gas field we used to get straw, which we used as fuel. Now there's nothing here and we have to buy fuel. We had fish and the land was fertile; now a whole month will go by and we don't eat fish. Where are the fish? There is no water in the river. But for our crops water logging is a big problem. When the road was built they promised culverts but the pipes are too narrow and the water can't pass through. We want deep tube wells in the area; it will provide water to our land. We can survive by farming. Otherwise we will die. ${ }^{15}$

In the next account, given by a young woman in the village directly opposite the gas field, the fertility of the soil is directly linked to the extraction of gas, which has been channelled outside. This has left 'the ground empty'. The imagery is vivid, the analysis acute: the wealth of the fields has been pumped away, the once fertile and sustaining land left empty and denuded. How different this is from the description by Chevron's community relations officer, who, as noted above, told us:

When we first came here there was nothing. Paddy doesn't grow like it used to; the fertility of the soil has decreased. A farmer used to get ten maund of paddy from one kiare (one third of an acre) of land, but now he only gets four. People think the soil fertility has decreased due to use of machinery. They think our hidden wealth (the gas) has been channelled outside-the riches underground have been brought to the surface, leaving the ground empty. It is this which has affected the fertility of the soil..$^{16}$

The next narrator draws upon similar imagery: the gas is being extracted from the land, leaving an emptiness that will lead to death:

The gas field has killed us. We've lost land [...]. Trees are being destroyed by the gas. In my garden, the beans plants are all dying [...]. Because the gas is being extracted from the land there's nothing left underneath. The whole village will be drowned; we'll turn into a river. ${ }^{17}$

32 In his moving account of the altered landscapes created by the Oki Tedi copper and gold mine in Papua New Guinea, Kirsch describes how as they face their emptied out and transformed landscape, the Yonggom experience acute rupture, not only of their livelihoods, but also of their history and identity. He writes: 'What is the meaning of these empty places? Given the relationship between place and memory, the destruction of these landscapes also threatens history. These are not just empty places, but also scenes of loss' (Kirsch 2006: 190).

The fact that the altered environment disrupts memories and symbolic forms of connection as well as actual livelihoods is powerfully evoked by Samsun Khan, one of the people to have lost the most land. He told us about looking out from his house onto a transformed landscape: no longer the vista of family fields he had seen since childhood, but the gas field, which has caused a 'fire to burn in my heart'. A similar sense of 
disconnection from the landscape and his memories of the desh as a beautiful, peaceful place was evoked by one of the British men we got to know over the course of the research. In a discussion about the environmental effects of the gas field, which is situated only a few hundred feet from his bari, Tufael told of us the shock and sense of dis-location on returning to find what had happened in the fields next door. He described the smell and noise: 'It's like living on top of an industrial site'. ${ }^{18}$

\section{Conclusion}

In this paper we have shown how different imaginings of Bangladeshi development and un-development were used by groups in claims and contestations over Chevron's operation of a gas field in Sylhet from 2008-2011. In their Public Relations and Community Engagement work Chevron drew upon imaginings of grass-roots, small scale community development and nationalist discourses of economic growth and modernisation to assert the moral legitimacy of their activities. The hope was that after a spate of protests in Dhaka and globally, the brand would be recast with a 'friendly face' (Shever, 2010) and further reputational risks averted. The corporation's presence in the area was, however, contested by locals who drew upon dystopian imagery in their accounts of environmental destruction and dispossession which they linked to the gas field. This un-development is the dark autonym of the positive development they had hoped for: jobs, economic opportunities, increased incomes and security.

Whilst revolving around the gas field and Chevron's work in Bangladesh, all accounts were underlain by hopes and aspirations for a better future. Even though there was disagreement over so much, what was beyond dispute was that unnoyon (development) in whatever shape or form, was a good thing. In Chevron's imagining, the corporation and its executives contribute to the development efforts of local communities (romantically framed as 'proud' and 'resilient'); they are welcome partners, fighting poverty and 'empowering' at the same as turning a profit. In the accounts of those who opposed them, development in the form of modernisation and economic security was desired but Chevron failed to deliver it. To this extent, everyone concerned wanted the same thing: an end to poverty, a new dawn of modernisation and the opportunity to make money. What was disputed was how to go about achieving that end.

Clearly, these opposing accounts carried different political weight. Whilst Chevron's glossy representations of community development and partnership were circulated in corporate reports and websites, the locals' stories were dismissed by them as nothing more than unsubstantiated gossip or hearsay, and were not heard outside the area. As Chevron executives countered, when we shared our research with them in Dhaka, the accounts of environmental damage and ongoing poverty were based on rumours, not scientific, quantitative evidence. They were only too aware of the complaints, they said. In fact there were so many of them they could not countenance setting up formal grievance procedures (as our report suggested).

Finally, there is a twist, illustrating not just how fast material conditions can change but also how narratives are historically and politically shaped. On returning to the area in early 2014 we found that gas extraction in the area had significantly increased. Many hundreds of local men had found employment in the construction of new roads and pipelines, as well as within the enclosure of a new installation several miles to the north. In the villages adjacent to the South Pad where we carried out our original research, 
many men had now been given jobs and the story had significantly shifted. Rather than being associated with destruction and dispossession, the gas field was once again a source of hope-regular wages, security-and maybe more in the form of long term employment, modernisation and inclusion in the formal economy. In the wider area, jobs (chakri) rather than Chevron or the gas field had become the site of contestation, with conflicts taking place between villages and factions in their struggles over employment contracts. As we write, the story is fast unfolding. Once again unnoyon is placed at the centre of the population's aspirations, dreams and struggles.

Adnan, Shapan (2013) 'Land Grabs and Primitive Accumulation in Deltaic Bangladesh: Interactions between Neoliberal Globalization, State Interventions, Power Relations and Peasant Resistance', The Journal of Peasant Studies, 40(1), pp. 87-128.

\section{BIBLIOGRAPHY}

Abram, Simone; Gisa Weszkalnys (eds.) (2013) Elusive Promises: Planning in the Contemporary World, 11, Oxford: Berghahn Books.

Akram-Lodhi, A. Haroon (2009) 'Modernising Subordination? A South Asian Perspective on the World Development Report 2008: Agriculture for Development', The Journal of Peasant Studies, 36 (3), pp. 611-19

Alam, Shawkat; Al Faruque, Abdullah (2009) 'Tragedy of Gas and Coal Exploration in Bangladesh: Towards Ensuring Corporate Environmental Accountability', Asia Pacific Journal of Environmental Law, 12(1), pp. 117-148.

Batliwala, Srilatha (2007) 'Taking the Power Out of 'Empowerment': An Experiential Account', Development in Practice, 17, (4-5), pp. 557-65.

Centre for Women and Child Studies (2006) ‘Baseline Study of Unocal Working Area’ Dhaka.

Chevron Publications (2008) Bibiyana Gas Field First Anniversary Report, Dhaka: Chevron.

Corbridge, Stuart; Shah, Alpa (2013) 'Introduction: The Underbelly of the Indian Boom.' Economy and Society, 42(3), pp. 335-47.

Cornwall, Andrea; Eade, Deborah (eds.) (2010) Deconstructing Development Discourse: Buzzwords and Fuzzwords, London: Practical Action Publishing.

Cross, Jamie (2011) 'Detachment as a Corporate Ethic: Materializing CSR in the Diamond Supply Chain' Focaal 60, pp. 34-46.

Cross, Jamie (2014) Dream Zones: Anticipating Capitalism and Development in India, London: Pluto Press.

Donnan, Hastings; Simpson, Kirk (2007) 'Silence and Violence among Northern Ireland Border Protestants', Ethnos, 72(1), pp. 5-28.

Dreze, Jean; Sen, Amartya (2013) An Uncertain Glory: India and its Contradictions, London: Penguin.

Eyben, Rosalind. (2005) 'Battles Over Booklets: Gender Myths in the British Aid Programme’, IDS Bulletin, 35(4), pp. 73-81. 
Faruque, Omar (2012) The Phulbari Movement: Political Struggle against Neoliberal Development in Bangladesh, University of Waterloo-Wilfrid Laurier University.

Feldman, Shelley; Geisler, Charles (2012) 'Land Expropriation and Displacement in Bangladesh', The Journal of Peasant Studies, 39(3-4), pp. 971-93.

Ferguson, James. (1990) The Anti-politics Machine: 'Development', Depoliticization, and Bureaucratic Power in Lesotho, Cambridge: Cambridge University Press.

Fortun, Kim (2009) Advocacy after Bhopal: Environmentalism, Disaster, New Global Orders, Chicago: University of Chicago Press.

Gain, Philip (2006) 'Killings in Phulbari Ignite Unstoppable Protest: Local Communities Stand Strong against Open Cut Mining', Dhaka: Society for Environment and Human Development.

Gardner, Katy (1995) Global Migrants, Local Lives: Migration and Transformation in Rural Bangladesh, Oxford: Oxford University Press.

Gardner, Katy (2008) 'Keeping Connected: Security, Place and Social Capital in a Londoni Village in Sylhet', Journal of the Royal Anthropological Institute (JRAI), 14(3), pp. 447-95.

Gardner, Katy (2012) Discordant Developments: Global Capital and the Struggle for Connection in Bangladesh, London: Pluto Press.

Gardner, Katy; Bashar, Fatema.; Rana, Mushir; Ahmed, Zahir (2012) 'Elusive Partnerships: CSR and Gas Extraction in Bangladesh', Resources Policy, 37(2), pp. 168-74.

Guhathakurta, Meghna. (2013) 'Poverty, Gender and Shrimps', in Meghna Guhathakurta \& Willem van Schendel, (eds.) (2013) The Bangladesh Reader: History, Culture, Politics, Durham: Duke University Press, pp. 457-561.

Gurhathakurta, Meghna; van Schendel, Willem (eds.) (2013) The Bangladesh Reader: History, Culture, Politics, Durham: Duke University Press.

Hussain, Delwar (2013) Boundaries Undermined: The Ruins of Progress on the Bangladesh Border, London: Hurst \& Co.

Ito, Sanae (2002) 'From Rice to Prawns: Economic Transformation and Agrarian Structure in Rural Bangladesh', The Journal of Peasant Studies, 29(2), pp. 47-70.

Jordan Smith, Daniel (2007) A Culture of Corruption: Everyday Deception and Popular Discontent in Nigeria, Princeton: Princeton University Press.

Kirsch, Stuart (2006) Reverse Anthropology: Indigenous analysis of social and environmental relations in New Guinea, Stanford: Stanford University Press.

Le Mons Walker, Kathy (2008) 'Neoliberalism on the Ground in Rural India: Predatory Growth, Agrarian Crisis, Internal Colonization, and the Intensification of Class Struggle', The Journal of Peasant Studies, 35(4), pp. 557-620.

Lewis, David (2011) Bangladesh: Politics, Economy and Civil Society, Cambridge: Cambridge University Press.

Li, Tanya (2007) The Will to Improve: Governmentality, Development and the Practice of Politics, Durham \& London: Duke University Press.

Mosse, David (2005) Cultivating Development: An Ethnography of Aid Policy and Practice, London: Pluto Press.

Nuremowla, Sadid Ahmed (2012) Resistance, Rootedness and Mining Protest, University of Sussex DPhil thesis. 
Ong, Aihwa (2006) Neoliberalism as Exception: Mutations in Citizenship and Sovereignty, Durham \& London: Duke University Press.

Pattenden, Jonathan (2010) 'A Neo-liberalism of Civil Society? Self Help Groups and the Labouring Class Poor in Rural South India', The Journal of Peasant Studies 37(3), pp. 485-512.

Rogers, Douglas (2012) 'The Materiality of the Corporation: Oil, Gas, and Corporate Social Technologies in the Remaking of a Russian Region', American Ethnologist, 39(2), pp. 284-96.

Ross, Fiona (2003) 'On Having Voice and Being Heard: Some After Effects of Testifying Before the South African Truth and Reconciliation Commission', Anthropological Theory 3(3), pp. 325-41.

Rottenburg, Richard (2009) Far Fetched Facts: A Parable of Development Aid, Cambridge Mass: Massachusetts Institute of Technology.

Shever, Elana. (2010) 'Engendering the Company: Corporate Personhood and the 'Face' of an Oil Company in Metropolitan Buenos Aires', PoLAR, 33(1), pp. 26-45.

Smith, Howard James (2008) Bewitching Development: Witchcraft and the Reinvention of Development in Neo-Liberal Kenya, Chicago: Chicago University Press.

Welker, Marina (2009) “Corporate Security Begins in the Community': Mining, the CSR Industry and Environmental Advocacy in Indonesia', Cultural Anthropology, 24(1), pp. 142-79.

Welker, Marina (2012) 'The Green Revolution's Ghost: Unruly Subjects of Participatory Development in Rural Indonesia', American Ethnologist, 39(2), pp. 389-406.

West, H. (2003) ‘Voices Twice Silenced: Betrayal and Mourning at Colonialism's End in Mozambique’, Anthropological Theory, 3(3), pp. 343-65.

White, Sarah (1994) Arguing with the Crocodile: Gender and Class in Bangladesh, London: Zed Press.

Zalik, Anna (2004) ‘The Niger Delta: ‘Petro Violence' and 'Partnership Development.' Review of African Political Economy, 31(101), pp. 401-24.

\section{NOTES}

1. For a summary of recent development successes of Bangladesh, see Drèze \& Sen, 2013: 58-64.

2. This is clearly an oxymoron.

3. See http://archive.thedailystar.net/beta2/news/gas-shock-halts-life/ (accessed 12/2/14)

4. For a more lengthy discussion of labour hiring practices during the research period, see Gardner 2012.

5. A typical quote from a focus group discussion, 2009.

6. Research notes, 2009.

7. This comment was made by a Chevron executive during a workshop on Corporate Social Responsibility held in Dhaka in January 2011.

8. Interview notes, 2008.

9. Matin Khan, cited in Chevron (2008: 40).

10. Chevron Bangladesh Newsletter, Year Y, Issue 2, July 2008.

11. Chevron Bangladesh Newsletter, Year Y, Issue 2, July 2008.

12. See for example http://bangladeshwatchdog.blogspot.co.uk/2009/09/oil-gas-and-mineralresources-of-our.html (accessed 13/02/14)

13. For discussion of 'giving voice' through stories in contexts of violence, see Ross 2003, West 2003, Donnan \& Simpson 2007.

14. Interview notes, 2009. 
15. Interview notes, 2008.

16. Interview notes, 2008.

17. Interview notes, 2009.

18. Interview notes, 2009.

\section{ABSTRACTS}

In this article we analyse the discourses which surrounded a Chevron operated gas field and programme of 'Community Engagement' in Sylhet over 2008-11. All draw upon ideas of development or its absence, and reference dreams, as well as nightmares of the future. On the one hand are Chevron's narratives, which conjure up an appealing picture of community development, entrepreneurship and 'empowerment', relying upon idioms of sustainability and 'helping people to help themselves'. On the other are the narratives of people living in the villages surrounding the installation. Whilst for them, dreams of unnoyon (development) involve the provision of local services, access to gas and the creation of jobs, their accounts evolve around the tropes of environmental destruction and disastrous rupture: a dystopian antidevelopment.

\section{INDEX}

Keywords: development, Gas field, Corporate-Social-Responsibility, environment

\section{AUTHORS}

\section{KATY GARDNER}

Professor of Anthropology, the London School of Economics

\section{ZAHIR AHMED}

Professor of Anthropology, Jahangirnagar University, Savar, Dhaka, Bangladesh

\section{MOHAMMAD MASUD RANA}

Assistant Professor of Anthropology, Jahangirnagar University, Savar, Dhaka, Bangladesh

\section{FATEMA BASHAR}

Assistant Professor of Anthropology, Jagganath University, Dhaka, Bangladesh 